\title{
Perubahan nilai pH dan Jumlah Bakteri Ikan Nila (Oreochromis niloticus) Hasil Pengawetan Larutan Daun Matoa (Pometia pinnata)
}

\author{
Rieny Sulistijowati*, Tomi J. Ladja dan Rita Marsuci Harmain \\ Teknologi Hasil Perikanan, Fakultas Perikanan dan Ilmu Kelautan, Universitas Negeri Gorontalo \\ Jl. Jenderal Sudirman No.06 Kota Gorontalo 96000, Gorontalo, Indonesia. \\ *Korespondensi: rienysulistijowati@ung.ac.id \\ (Diterima 19-05-2020; Direvisi 04-07-2020; Dipublikasi 13-07-2020)
}

\begin{abstract}
This research was conducted to find out quality of fresh tilapia (Oreochromis niloticus) $\mathrm{pH}$ and bacteria number preserved using a matoa leaf extract (Pometia pinnata). The treatment was carried out long time storage of fresh tilapia for 12,18 and 24 hours preserved with $15 \%$ matoa leaf extract at $\pm 27^{\circ} \mathrm{C}$. Analysis of $\mathrm{pH}$ and total bacterial values using a Completely Randomized Design (CRD). Based on the results of the study showed that the use of matoa leaf extract with a concentration of $15 \%$ was able to maintain the quality of fresh tilapia for 12 hours storage at $\pm 27^{\circ} \mathrm{C}$ obtained a $\mathrm{pH}$ value of 6.88 and microbiologically obtained a $\log$ value of the bacterial amount of $5.26 \mathrm{Cfu} / \mathrm{g}$ by inhibiting the number of bacteria $1.56 \mathrm{Cfu} / \mathrm{g}$. This fulfills the SNI 01-2729-2013 requirements regarding fresh fish.
\end{abstract}

Keywords: Bacteria number, bio-preservative, Matoa Leaves extract, Pometia pinnata, pH; Tilapia, Oreochromis niloticus.

Penelitian ini dilakukan dengan tujuan untuk mengetahui mutu kesegaran ikan nila, yaitu pH dan jumlah bakteri ikan nila (Oreochromis niloticus) segar yang diawetkan dengan menggunakan ekstrak daun matoa (Pometia pinnata). Perlakuan yang dilakukan yaitu lama penyimpanan ikan nila segar selama 12 , 18 dan 24 jam yang diawetkan dengan ekstrak daun matoa $15 \%$ pada suhu $\pm 27^{\circ} \mathrm{C}$. Analisis data nilai $\mathrm{pH}$ dan total bakteri menggunakan Rancangan Acak Lengkap (RAL). Berdasarkan hasil penelitian menunjukkan bahwa penggunaan ekstrak daun matoa dengan konsentrasi $15 \%$ mampu mempertahankan mutu ikan nila segar selama penyimpanan 12 jam pada suhu $\pm 27^{\circ} \mathrm{C}$ diperoleh nilai $\mathrm{pH} 6,88$ dan secara mikrobiologi diperoleh nilai log jumlah bakteri $5,26 \mathrm{Cfu} / \mathrm{g}$ dengan penghambatan jumlah bakteri 1,56 Cfu/g. Hal ini memenuhi syarat SNI 01-2729-2013 tentang ikan segar.

Kata kunci: Ekstrak Daun Matoa, Pometia pinnata, bio-preservative, Nila, Oreochromis niloticus, Jumlah Bakteri, pH.

\section{PENDAHULUAN}

Ikan nila memiliki kandungan gizi sangat baik antara lain protein $17,3 \%$, kadar air $80,7 \%$, dan lemak $0,33 \%$. Di sisi lain ikan mudah busuk karena mengandung kadar protein yang tinggi dengan kandungan asam amino bebas yang digunakan untuk metabolisme mikroorganisme, produksi amonia, biogenik amine, asam organik, ketone dan komponen sulfur, sehingga secepat mungkin perlu dilakukan pengawetan. Kondisi ikan yang segar mampu mempertahankan gizi ikan, untuk menghindari kemunduran mutu ikan, perlu cara untuk memperlambat pembusukan diantaranya pendinginan.

Es mampu memperpanjang shelf-life ikan (Oehlenschläger, 2010). Tingginya suhu di daerah tropis dan rendahnya kesadaran penerapan sanitasi dan higienis menyebabkan ikan lebih cepat busuk. Untuk menghindari penggunaan bahan-bahan pengawet yang dilarang seperti formalin sebagai akibat meningkatnya biaya pembelian es, maka perlu menggunakan bio-preservative dari bahan alami agar bahan pangan aman dikonsumsi. Pengawetan bertujuan untuk menghambat pertumbuhan mikroorganisme pada ikan sehingga dapat memperpanjang masa simpan bahan pangan. Pengawetan alami merupakan salah satu metode penghambatan pertumbuhan mikroorganisme pada ik an dengan menggunakan bahan alami yang mengandung senyawa bioaktif. Salah satu tumbuhan yang dapat dimanfaatkan untuk mengawetkan ikan adalah tumbuhan pertanian seperti daun matoa (Pometia pinnata) (Sipayung et al., 2015).

Daun matoa sejauh ini telah digunakan oleh masyarakat sebagai salah satu bahan untuk menurunkan kadar gula darah bagi penderita diabetes (Suryani et al., 2015). Kuspradini, et al., 
(2016) menyatakan bahwa ekstrak daun matoa memiliki kemampuan yang cukup kuat dalam menghambat pertumbuhan bakteri seperti Streptococcus mutans, Streptococcus sobrinus, Escherichia coli. Berdasarkan hasil penelitian Ladja, et al., (2019), menunjukkan bahwa penggunaan ekstrak daun matoa dengan konsentrasi 15\% mampu mempertahankan mutu ikan nila (Oreochromis niloticus) segar selama penyimpanan 12 jam secara organoleptik mutu hedonik dimana kriteria kenampakan bola mata rata, kornea dan pupil jernih, agak mengkilap spesifik jenis ikan. Warna insang merah tua atau cokelat kemerahan, kurang cemerlang dengan sedikit lendir transparan. Lapisan lendir mulai agak keruh, daging dinilai baik karena sayatan daging cemerlang spesifik jenis, jaringan daging kuat. Bau segar, spesifik jenis kurang dan tekstur masih dapat diterima karena padat, kompak, dan elastis. Selain faktor konsentrasi bahan pengawet, perubahan mutu dapat dipengaruhi oleh komposisi daging ikan, jenis komponen aktif, lama penyimpanan, suhu penyimpanan dan lain lain (Nihali, et al., 2020).

Penelitian pengawetan ikan nila segar menggunakan pengawetan alami antara lain daun sirih (Devi, 2015), buah mangrove (Pariansyah, et al., 2018), belimbing wuluh (Setyawati, 2014), lengkuas (Hidayah, et al., 2015). Sebagai pengawet, daun matoa adalah tumbuhan bagian dari hasil pertanian yang memiliki kandungan senyawa bioaktif sebagai antibakteri saat ini belum dimanfaatkan oleh masyarakat. Sehingga penulis melakukan penelitian ini untuk mengetahui mutu ikan nila segar secara kimiawi dan mikrobiologi yang diawetkan dengan menggunakan ekstrak daun matoa selama penyimpanan suhu kamar $\left( \pm 27^{\circ} \mathrm{C}\right)$.

\section{METODE PENELITIAN}

\section{Material}

Bahan baku yang digunakan yaitu sampel ikan nila segar berasal dari Danau Limboto, Kabupaten Gorontalo dan daun matoa diperoleh dari Kelurahan Tapa Jalan Rusli Datau Kecamatan Sipatana Kota Utara Gorontalo. Bahan yang digunakan uji TPC (Total plate count) adalah media BFP (Butterfied Phosphate), media PCA (Plate Count Agar), akuades, alkohol dan spriptus. Bahan uji $\mathrm{pH}$ yaitu indikator $\mathrm{pH} 4, \mathrm{pH} 7$ dan $\mathrm{pH} 10$. Alat yang digunakan uji $\mathrm{pH}$ yaitu menggunakan beker glass dan pH-meter. Alat uji TPC antara lain cawan petri, tabung reaksi, rak tabung, gelas ukur, gelas beker, erlenmeyer, spatula, vortex, hot plate, incubator, colony counter, neraca analitik, bunsen, dan autoclave.

\section{Pembuatan Ekstrak Daun Matoa (Devi, 2015)}

Pembuatan ekstrak daun matoa menurut Devi (2015) yang dimodifikasi yaitu pengambilan daun matoa dan konsentrasi. Pengambilan sampel daun dipisahkan dari batangnya dan penanganan daun matoa (pemilihan daun). Selanjutnya perobekan daun dilakukan dengan cara menggunting menjadi lembaran-lembaran kecil. Pembuatan konsentrasi ekstrak daun matoa $15 \%$ menggunakan air suling dan blender dan pemanasan dilakukan pada suhu $\pm 40^{\circ} \mathrm{C}$ selama 15 menit. Untuk mendapatkan ekstrak larutan daun matoa dilakukan penyaringan.

\section{Pengawetan Ikan Nila dengan Ekstrak Daun Matoa}

Pengambilan sampel yaitu ikan nila dalam keadaan hidup, dimatikan dengan cara dipukul pada bagian kepala. Hasil penyaringan ekstrak daun 15\% untuk perendaman ikan nila segar dengan lama perendaman selama 30 menit lalu ikan diangkat dan disimpan selama12, 18 dan 24 jam pada suhu $\pm 27^{\circ} \mathrm{C}$. Kontrol menggunakan ikan nila tanpa pengawetan dan disimpan selama 12, 18 dan 24 jam. Parameter pengujian yaitu nilai $\mathrm{pH}$ dan total bakteri selama penyimpanan.

\section{Nilai pH}

Menurut Bawinto (2015), bahwa penentuan $\mathrm{pH}$ dapat dilakukan dengan menggunakan $\mathrm{pH}$ meter, dengan urutan kerja sebagai berikut: menyiapkan larutan standar $\mathrm{pH} \mathrm{4,7}$ dan 10. Timbang sampel yang telah dirajang kecil-kecil sebanyak 10 gram. Sampel dituang ke dalam beker glass 10 $\mathrm{ml}$, kemudian diukur nilai $\mathrm{pH}$-nya dengan menggunakan alat $\mathrm{pH}$-meter. Sebelum $\mathrm{pH}-\mathrm{meter}$ digunakan, harus ditera kepekaan jarum penunjuk dengan larutan buffer $\mathrm{pH}$ 7. Besarnya $\mathrm{pH}$ adalah pembacaan jarum penunjuk $\mathrm{pH}$ setelah jarum skala konstan kedudukannya.

\section{Penentuan Jumlah Bakteri (Total Plate Count) (SNI 01-2332-3-2006)}


Metode penentuan angka lempeng total atau TPC yaitu digunakan untuk menentukan jumlah total mikroorganisme aerob dan anaerob yang terdapat pada produk perikanan. Kesegaran ikan merupakan kriteria paling penting untuk menentukan mutu dan daya awet dari ikan yang diinginkan. Pengukuran ini menggunakan metode TPC yang dilakukan dengan cara menghitung jumlah bakteri yang ditumbuhkan pada suatu media pertumbuhan (media agar) dan diinkubasi selama 48 jam pada

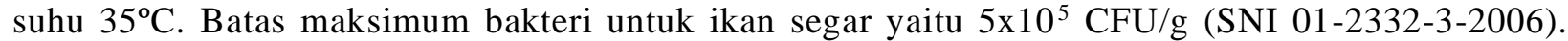
Prinsip kerja analisis TPC adalah menghitung jumlah bakteri yang ada di dalam sampel (ikan) dengan pengenceran. Metode hitungan cawan merupakan cara yang sensitif untuk menentukan untuk menentukan jumlah jasa renik. Penentuan angka lempeng total yang dilakukan berdasarkan SNI 01 2332-3-2006 dengan prosedur sebagai berikut:

1. Semua peralatan yang digunakan disterilkan terlebih dahulu dalam oven pada suhu $110^{\circ} \mathrm{C}$ selama 2 jam.

2. Sampel ikan nila segar ditimbang secara aseptic sebanyak 25 gram.

3. Media PCA ditimbang seberat 3,525 gram (untuk pengujian 1 sampel), kemudian PCA dimasukan ke dalam Erlenmeyer yang berisi $150 \mathrm{ml}$ akuades dan disterilkan dalam autoclave bersamaan dengan BFP.

4. Media PCA dipanaskan pada hot plate yang dilengkapi dengan magnetic stirrer sampai larutan menjadi jernih.

5. Sampel ikan nila segar yang sudah ditimbang dimasukan ke dalam plastik steril yang sudah berisi larutan BFP sebanyak $225 \mathrm{ml}$, kemudian dihomogenkan pada alat stomacher.

6. Sampel ikan dan larutan BFP yang sudah homogen, diambil sebanyak $1 \mathrm{ml}$ lalu masukkan ke dalam tabung reaksi yang berisi $9 \mathrm{ml}$ BFP $\left(10^{-2}\right)$, kemudian diambil $1 \mathrm{ml}$ dari pengenceran $10^{-2}$ dan dimasukkan ke dalam tabung reaksi yang berisi larutan BFP sebanyak $9 \mathrm{ml}\left(10^{-3}\right)$ sampai pada pengenceran $10^{-5}$.

7. Pipet $1 \mathrm{ml}$ dari setiap pengenceran tadi ke dalam cawan petri steril (dilakukan secara duplo untuk setiap pengenceran), kemudian dituangkan PCA yang sudah dingin sampai suhu $45^{\circ} \mathrm{C}$ sebanyak $12-15 \mathrm{ml}$ ke dalam cawan petri yang berisi pengenceran tadi, kemudian dikocok sampai tercampur dan didiamkan sampai membentuk agar.

8. Cawan petri tersebut dimasukan ke dalam incubator, selama 24-48 jam dengan toleransi selama \pm 2 jam.

9. Koloni yang tumbuh pada cawan petri dihitung dengan menggunakan colony counter.

10. Total koloni dihitung dengan perhitungan metode Harrigan. Rumus untuk menghitung total koloni mikroba dengan metode Harrigan, yaitu:

$$
\begin{array}{ll}
\mathrm{N}= & \sum \mathrm{C}[(1 \times \mathrm{n} 1)+(0,1 \times \mathrm{n} 2 \times \mathrm{n} 2)] \times \mathrm{d} \\
\mathrm{Ket} . & \mathrm{N}: \text { jumlah koloni produk, dinyatakan dalam koloni per ml atau koloni per gram; } \\
& \sum \mathrm{C}: \text { jumlah koloni pada semua cawan yang dihitung; } \\
\mathrm{n} 1: \text { jumlah cawan pada pengenceran pertama yang dihitung; } & \mathrm{n} 2: \text { jumlah cawan pada perhitungan kedua yang dihitung; } \\
\mathrm{d}: \text { pengenceran pertama yang dihitung. }
\end{array}
$$

\section{Rancangan Penelitian dan Analisis Data}

Desain yang digunakan yaitu eksperimen Rancangan Acak Lengkap (RAL) non faktorial dengan 6 perlakuan (Kontrol simpan 12 jam, kontrol simpan 18 jam, kontrol simpan 24 jam, rendam simpan 12 jam, rendam simpan 18 jam dan rendam simpan 24 jam). Kontrol tanpa perendaman ekstrak daun matoa, Parameter uji mutu ikan nila segar yaitu $\mathrm{pH}$ dan total bakteri. Data dianalisis menggunakan ANOVA dan uji lanjut Duncan.

\section{HASIL DAN PEMBAHASAN}

\section{Nilai pH Ikan Nila (Oreochromis niloticus)}

Data nilai pH ikan nila yang diawetkan dengan ekstrak daun matoa selama penyimpanan suhu ruang dapat dilihat pada Gambar 1.

Berdasarkan Gambar 1, menunjukkan bahwa nilai pH ikan nila tanpa pengawetan mengalami peningkatan selama penyimpanan $24 \mathrm{Jam}$. Namun, selama penyimpanan 24 Jam nilai pH ikan nila yang menggunakan ekstrak daun matoa lebih rendah dibandingkan dengan nilai $\mathrm{pH}$ ikan yang tanpa menggunakan ekstrak daun matoa. Nilai $\mathrm{pH}$ pada penyimpanan 12 Jam tanpa pengawetan yaitu 7,10 
sedangkan pada penyimpanan yang sama menggunakan ekstrak daun matoa yaitu 6,88. Pada penyimpanan 18 jam nilai $\mathrm{pH}$ ikan tanpa pengawetan naik 7,36, pada penyimpanan yang sama menggunakan ekstrak daun matoa nilai $\mathrm{pH}$ yaitu 7,29. Pada penyimpanan 24 jam nilai $\mathrm{pH}$ ikan tanpa pengawetan yaitu 7,86, pada penyimpanan menggunakan ekstrak daun matoa nilai pH ikan 7,76.

Berdasarkan hasil analisis Uji One Way ANOVA yang digunakan untuk menguji pengaruh pH tingkat keasaman ikan bahwa pada lama penyimpanan, tidak berpengaruh nyata $(\mathrm{P}>0,05)$ terhadap peningkatan nilai $\mathrm{pH}$ ikan nila.

Nilai pH merupakan salah satu indikator atau parameter yang digunakan untuk menentukan tingkat kesegaran ikan. Pada daging ikan kandungan $\mathrm{pH}$ biasanya berada antara 6,4-6,6 atau mendekati nilai $\mathrm{pH}$ netral. Jika $\mathrm{pH}>7$ atau di atas nilai $\mathrm{pH}$ netral, maka ikan akan mudah mengalami kerusakan, karena rendahnya cadangan glikogen dalam daging ikan (Anggraini, 2018).

Nilai pH daging ikan nila pada penyimpanan suhu kamar 12 jam masih dapat diterima. Hal ini nilai $\mathrm{pH}$ pada penyimpanan $12 \mathrm{Jam}$ masih termasuk $\mathrm{pH}$ ikan segar dimana ikan masih dapat dikonsumsi. Penyimpanan 18 dan 24 Jam terjadi peningkatan nilai $\mathrm{pH}$ yang sudah melewati batas pH ikan segar dimana ikan tidak masuk kriteria untuk dikonsumsi lagi. Peningkatan nilai pH pada daging ikan sangat berhubungan dengan cadangan glikogen dalam tubuh ikan dan cara mematikan ikan. Menurut Munandar, et al., (2009), kecepatan peningkatan nilai pH pada ikan nila ini disebabkan ikan tersebut mati menggelepar dan banyak mengeluarkan energi sehingga cadangan glikogen yang tersedia pada daging hanya sedikit. Ikan yang mengeluarkan banyak energi sebelum mati, $\mathrm{pH}$ ikan lebih cepat mengalami peningkatan dan mengaktifkan enzim katepsin mampu menguraikan senyawasenyawa yang bersifat volatil.

Nilai pH mengalami kenaikan karena pembentukan ammonia akibat aktivitas enzim proteolitik. Kenaikan nilai $\mathrm{pH}$ juga disebabkan oleh adanya proses reduksi trimetilamin oksida (TMAO) menjadi senyawa yang bersifat basa yaitu trimetilamin (TMA) yang didegradasi oleh bakteri. Ikan laut dan ikan air tawar mengandung trimetilamin oksida yang didegradasi oleh beberapa bakteri menjadi trimetilamin. Trimetilamin terbentuk dari hasil reduksi trimetilamin oksida oleh enzim yang berasal dari daging ikan atau mikroba, perombakan trimetilamin oksida menjadi trimetilamin merupakan reaksi penting dari kerusakan ikan secara enzimatis (Santoso, et al., 2017).

Menurut Murniyati dan Sunarman (2000), aksi bakteri dimulai pada saat yang hampir bersamaan dengan terjadinya autolisis, dan kemudian berjalan sejajar dengan kenaikan nilai $\mathrm{pH}$. Perubahan $\mathrm{pH}$ ikan juga dipengaruhi oleh faktor eksternal seperti suhu lingkungan serta faktor internal seperti komposisi kimia daging.

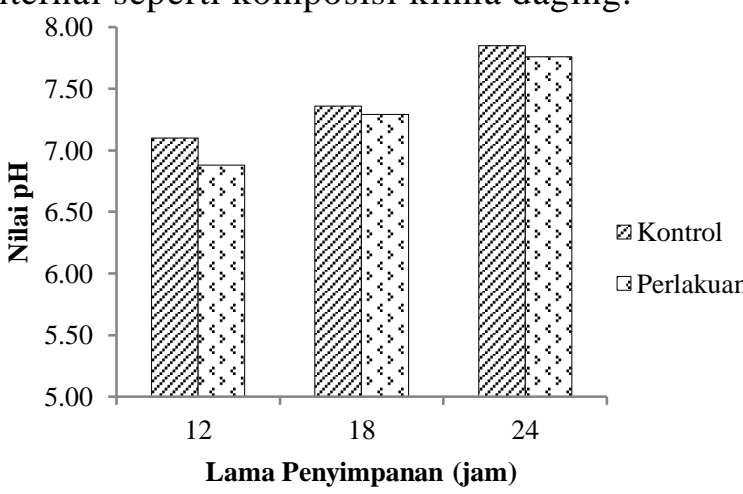

Gambar 1. Histogram pH Pada Ikan Nila (Oreochromis niloticus).

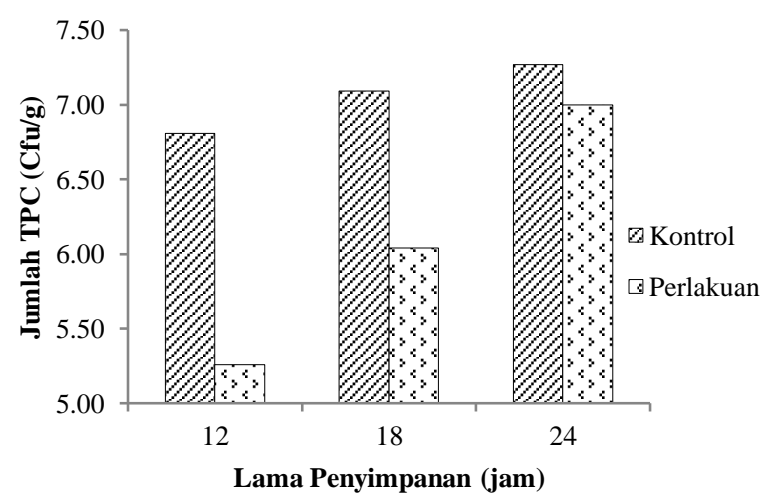

Gambar 2. Total Bakteri Ikan Nila Segar (Oreochromis niloticus).

\section{Nilai TPC Ikan Nila (O. niloticus)}

Nilai TPC ikan nila dengan dan tanpa perendaman ekstrak daun matoa selama penyimpanan pada suhu $\pm 27^{\circ} \mathrm{C}$ dapat dilihat pada Gambar 2. Gambar 2, menunjukkan bahwa jumlah total bakteri ikan nila selama penyimpanan pada suhu ruang $\left(27^{\circ} \mathrm{C}\right)$ mengalami peningkatan. Namun, peningkatan jumlah total bakteri ikan nila yang disimpan tanpa pengawetan berbeda dengan jumlah total bakteri ikan nila yang dilakukan penyimpanan menggunakan ekstrak daun matoa.

Hasil nilai log TPC ikan nila kontrol pada penyimpanan $12 \mathrm{Jam}$ yaitu $6,81 \mathrm{CFU} / \mathrm{g}$, setelah diberikan perlakuan ekstrak daun matoa pada penyimpanan 12 jam terjadi penghambatan jumlah 
bakteri yaitu 5,26 CFU/g, dan pada penyimpanan 18 jam tanpa pengawetan jumlah bakteri mulai meningkat yaitu 7,09 CFU/g dengan waktu yang sama, adanya ekstrak daun matoa mampu menghambat jumlah bakteri yaitu 6,04 CFU/g sedangkan pada penyimpanan 24 jam kontrol jumlah bakteri terus meningkat 7,27 CFU/g tetapi pada penyimpanan 24 jam ekstrak daun matoa masih mampu menghambat pertumbuhan bakteri dengan nilai $\log$ yaitu $7,00 \mathrm{CFU} / \mathrm{g}$. Hal tersebut menunjukkan bahwa ekstrak daun matoa mampu menurunkan atau menghambat pertumbuhan bakteri pada ikan nila dibandingkan tanpa pengawetan (kontrol).

Penggunaan ekstrak daun matoa mampu menghambat pertumbuhan bakteri pada ikan nila selama penyimpanan pada suhu $27^{\circ} \mathrm{C}$ yaitu pada jam ke-12 terjadi penurunan nilai TPC sebesar 1,55 $\log$, pada jam ke-18 sebesar 1,05 log dan pada jam ke-24 sebesar 0,27 log. Berdasarkan hasil analisis Uji One Way ANOVA lama penyimpanan berpengaruh nyata $(\mathrm{P}<0,05)$ terhadap penghambatan TPC ikan nila. Hasil uji lanjut Duncan menunjukkan bahwa penghambatan TPC semua taraf dengan lama penyimpanan 12, 18 dan 24 jam berbeda nyata.

Badan Standarisasi Nasional (2013) memberikan batasan atau syarat bahwa batasan jumlah TPC ikan segar adalah maksimal yaitu $5 \times 10^{5} \mathrm{CFU} / \mathrm{g}$. Pada penelitian ini menunjukkan bahwa senyawa yang terdapat pada daun matoa yang digunakan untuk mengawetkan ikan nila mampu menghambat pertumbuhan bakteri hingga 24 jam. Hal ini diduga bahwa jumlah bakteri pada ikan air tawar termasuk ikan nila jumlah bakteri terus meningkat selama penyimpanan 24 jam sehingga senyawa yang terkandung pada daun matoa tidak mampu lagi untuk menghambat pertumbuhan mikroorganisme yang ada pada ikan nila yang disimpan tersebut.

Kemampuan penghambatan total bakteri dimungkinkan karena ekstrak daun matoa mengandung alkaloid, tannin dan kumarin. Kuspradini, et al., (2016) menyatakan pengujian antimikroba dengan metode pewarnaan 2, 3, 5-triphenyl tetrazolium chloride (TTC) menunjukkan bahwa ekstrak daun matoa memiliki kemampuan yang cukup kuat dalam menghambat pertumbuhan bakteri Streptococcus mutans, Streptococcus sobrinus, Escherichia coli kecuali terhadap Propionibacterium acne.

Beberapa faktor yang mempengaruhi mutu ekstrak diantaranya yaitu faktor kimia seperti jenis dan jumlah senyawa kimia, metode ekstraksi dan pelarut yang digunakan. Selain itu, adanya variasi biologis, misalnya tempat asal daun yang digunakan. Faktor-faktor lingkungan seperti suhu udara, kelembaban relatif, radiasi matahari, angin, suhu tanaman, ketersediaan air, ketercukupan cahaya dalam proses fotosintesis sangat mempengaruhi fungsi fisiologis, bentuk anatomi dan siklus hidup tumbuhan. Pada daun yang masih terlihat muda mengandung zat-zat yang bersifat antibakteri, sedangkan pada daun yang sudah tua kandungannya berbeda (Sari, 2018).

Peningkatan Angka Lempeng Total (ALT) biasanya disebabkan dalam tubuh ikan tersedia kandungan gizi yang memadai sebagai sumber makanan dan media bagi pertumbuhan bakteri. Daging ikan merupakan substrat yang sangat baik untuk bakteri karena menyediakan senyawasenyawa yang dapat menjadi sumber nitrogen, karbon dan nutrien-nutrien lain untuk kebutuhan hidupnya (Hidayah, et al., 2015).

Menurut Anggraeni, et al., (2017), menyatakan adanya kandungan protein pada daun dapat dijadikan nutrisi bagi bakteri. Sehingga semakin tinggi konsentrasi larutan ekstrak daun, semakin tinggi pula kandungan protein yang terdapat di dalam larutan tersebut dan menyebabkan kandungan protein yang terkandung dalam larutan ekstrak dijadikan bakteri sebagai sumber nutrisi bagi pertumbuhannya sehingga pertumbuhan bakteri semakin cepat peningkatannya.

\section{KESIMPULAN}

Berdasarkan hasil penelitian yang telah dilakukan dapat disimpulkan bahwa mutu ikan nila (Oreochromis niloticus) segar yang diawetkan menggunakan larutan daun matoa (Pometia pinata) secara kimiawi (nilai $\mathrm{pH}$ ) penyimpanan 12 jam diperoleh nilai $\mathrm{pH}$ 6,88 dan secara mikrobiologi larutan daun matoa dapat menghambat pertumbuhan mikroorganisme pada ikan nila segar selama penyimpanan. Penyimpanan 12 jam jumlah bakteri memenuhi standar batasan SNI 01-2729-2013 ikan segar maksimal jumlah bakteri $5 \times 10^{5} \mathrm{CFU} / \mathrm{g}$ dengan nilai log 5,26 CFU/g. Sedangkan pada penyimpanan 18 jam dan 24 jam sudah tidak memenuhi standar SNI 2729-2013 ikan segar maksimal $5 \times 10^{5} \mathrm{CFU} / \mathrm{g}$. 


\section{UCAPAN TERIMAKASIH}

Terima kasih disampaikan kepada pimpinan dan analis Laboratorium Kesehatan Masyarakat (KESMAS) Fakultas Olahraga dan Kesehatan Masyarakat, Laboratorium Bioteknologi dan Karakteristik Teknologi Hasil Perikanan Universitas Negeri Gorontalo yang telah membantu menyediakan fasilitas pada saat penelitian.

\section{DAFTAR PUSTAKA}

Anggraeni, D.H., Pratama, R., dan Rostini, I. (2017). Pengaruh Konsentrasi Ekstrak Daun Jambu Biji Terhadap Masa Simpan Filet Patin Berdasarkan Jumlah Mikroba. Jurnal Perikanan Kelautan, 8(2).

Anggraini, M. 2018. Kualitas Ikan Tongkol (Euthynnus affinis) Dengan Pengawet Alami Ekstrak Daun Kemangi Pada Variasi Lama. Program Studi Pendidikan Biologi Fakultas Keguruan dan Ilmu Pendidikan Universitas Muhammadiyah Surakarta.

Badan Standardisasi Nasional Indonesia. 2013. Ikan Segar (SNI 2729-2013). Dewan Standarisasi Nasional Indonesia. Jakarta.

Bawinto, A.S., Mongi, E. dan Kaseger, B.E. 2015. Analisa Kadar Air, pH, Organoleptik, dan Kapang Pada Produk Ikan Tuna (Thunnus sp) Asap. Jurnal Media Teknologi Hasil Perikanan Vol. 3(2). Program Studi Teknologi Hasil Perikanan. Fakultas Perikanan dan Ilmu Kelautan. Unsrat Manado.

Devi, A.R. (2015). Pengawetan Ikan Nila (Oreochromis Niloticus) Menggunakan Daun Sirih Dengan Variasi Lama Perendaman Yang Berbeda (Doctoral dissertation, Universitas Muhammadiyah Surakarta).

Hidayah,Y, R. Winarni, dan Susatyo, B.E. 2015. Pengaruh Penggunaan Lengkuas Terhadap Sifat Organoleptik dan Daya Simpan Ikan Nila Segar. JurnalJurusan Kimia FMIPA Universitas Negeri Semarang.

Kuspradini, H., Pasedan, W.F., dan Kusuma, I.W. (2016). Aktivitas Antioksidan dan Antibakteri Ekstrak Daun Pometia pinnata. Jurnal Jamu Indonesia, 1(1): 26-34.

Ladja, T., Sulistijowati, R., dan Harmain, R.M. (2019). Mutu Ikan Nila (Oreochromis Niloticus) Segar Secara Organoleptik Yang Diawetkan Menggunakan Larutan Daun Matoa (Pometia Pinnata). Jambura Fish Processing Journal, 1(2): 46-51.

Munandar, A., dan Nurjanah, N.M. (2009). Kemunduran mutu ikan nila (Oreochromis niloticus) pada penyimpanan suhu rendah dengan perlakuan cara kematian dan penyiangan. Jurnal Pengolahan Hasil Perikanan Indonesia, 12(2): 88101.

Murniyati, A. S dan Sunarman. 2000. Pendinginan, Pembekuan dan Pengawetan Ikan. Kanisius, Yogyakarta.

Nihali, M.P., Sulistijowati, R., dan Yusuf, N. (2020). Pengawetan Ikan Tongkol (Euthynnus affinis) Menggunakan Sari Daun Jambu Biji (Psidium guajava) Selama Penyimpanan Suhu Ruang. Jambura Fish Processing Journal, 2(2): 2331.

Oehlenschläger, J., 2010. Introduction - importance of analysis in seafood and seafood products, variability and basic concepts. In: In: Handbook of Seafood and Seafood Product analysis. Edited by: Leo M.L. Nollet and Fidel Todrá.CRC Press. 69 Copyright@2011. Jurnal Perikanan (Journal of Fisheries Sciences) All Right Reserved Susanto et al., 2011 Taylor and Francis Group. Boca Rato. USA. 3-12.

Pariansyah, A., Herliany, N.E. dan Negara, B.F.S.P. (2018). Aplikasi maserat buah mangrove Avicennia marina sebagai pengawet alami ikan nila segar. Acta Aquatica: Aquatic Sciences Journal, 5(1): 36-44.

Santoso, M.A.R., Liviawaty, E., dan Afrianto, E. (2017). Efektivitas Ekstrak Daun Mangga Sebagai Pengawet Alami Terhadap Masa Simpan Filet Nila Pada Suhu Rendah. Jurnal Perikanan Kelautan, 8(2).

Sari, L, D. 2018. Uji Aktivitas Antibakteri Ekstrak Etanol Daun Sirsak Muda Dan Tua (Annona muricata L.) Terhadap Staphylococcus aureus. Program Ekstensi Sarjana Farmasi Fakultas Farmasi Universitas Sumatera Utara Medan.

Setyawati, M.A. (2014). Pemanfaatan Ekstrak Buah Belimbing Wuluh (Averrhoa bilimbi L.) Dengan Konsentrasi dan Lama Perendaman Yang Berbeda Sebagai Bahan Pengawet Ikan Nila (Oreochromis niloticus) Segar (Doctoral dissertation, Universitas Muhammadiyah Surakarta).

Sipayung, B.S., Ma'ruf, W.F., dan Dewi, E.N. (2015). Pengaruh senyawa bioaktif buah mangrove Avicennia marina terhadap tingkat oksidasi fillet ikan nila merah $O$. niloticus selama penyimpanan dingin. Jurnal Pengolahan dan Bioteknologi Hasil Perikanan, 4(2): 115-123.

Suryani, N.C., Permana, D.G.M., dan Jambe, A.A.G.N.A. 2015. Pengaruh Jenis Pelarut Terhadap Kandungan Total Flavonoid dan Aktivitas Antioksidan Ekstrak Daun Matoa (Pometia pinnata). Universitas Udayana, Bali. 